American Journal of Economics and Business Administration 3 (2): 259-269, 2011

ISSN 1945-5488

(C) 2011 Science Publications

\title{
Conservatism and Value Relevance: Evidence from the European Financial Sector
}

\author{
Panayotis Manganaris, Jordan Floropoulos and Irini Smaragdi \\ Department of Economics, Aristotle University of Thessaloniki, \\ Division of Business Administration, 54124 Thessaloniki, Greece
}

\begin{abstract}
Problem statement: We examine the levels of conservatism and value relevance existent in the financial sectors of three code-law European countries (Germany, France and Greece) and one common-law European country (UK). We investigate (a) whether conservatism exists during the last decade (1999-2008), (b) whether its level has changed over this period and (c) the impact of conservatism on the value relevance of earnings. Approach: We run regressions on two widely acclaimed models: The Basu's model for the measurement of conservatism and the Easton and Harris's model for the measurement of value relevance. We derive results for each country, but also for specific subgroups (pre- and post-IFRS period; low- and high-conservatism firms). Results: The results provide evidence that conservatism exists in all countries before the IFRS adoption and that its level has decreased after 2005 only in France and Germany. Moreover, in the post-IFRS period, investors' perception on value relevance has decreased in code-law countries and increased in the UK. Splitting the samples according to the level of conservatism reveals that-except for Germany-during 2005-2008 higher (lower) conservatism entails less (more) value relevant earnings, contrary to the 1999-2004 findings. Conclusions/Recommendations: The research provides insights considering the consequences of IFRS adoption in the EU. We demonstrate that the new accounting framework affects differently the levels of conservatism and value relevance in four illustrative accounting regimes. This result implies that the variety among deep-rooted institutional factors within Europe will continue to exist even after implementing IFRS. Furthermore, the decreased adjusted- $R^{2} s$ of Basu and Easton and Harris models in the post-IFRS period imply that the once prevailing models may not be working effectively in the new era.
\end{abstract}

Key words: Conditional conservatism, value relevance, financial sector, International Accounting Standards (IAS), International Financial Reporting Standards (IFRS), European Union (EU), specific subgroups

\section{INTRODUCTION}

Since the introduction of the International Accounting Standards (IAS) and subsequently the International Financial Reporting Standards (IFRS), advances in international financial accounting have taken a leap. From 2005 and onwards, European Union's (EU) listed companies are mandatorily using IFRS in their financial statements. This new set of standards-whose primary purpose is to enhance the quality of financial reporting-has not stopped evolving since its inception. Especially the financial sector is greatly affected by IFRS mainly due to the adoption of IAS 32 and 39, as well as the newer IFRS 4 and 7, which deal with the accounting treatment of financial instruments. This is the primary reason for selecting the financial sector for the purposes of this study.
In essence, the dispute around financial instruments' standards arises between those who consider that the new standards offer-among othersgreater value relevance and those who support that the old accounting regime preserves conservatism and verifiability. The most important representative of the former perception is the Joint Working Group of Standard Setters (1999), whose discussion paper proposes that all financial assets and liabilities should be measured at fair value, while all gains and losses resulting from changes in the fair value should be recognised in the income statement (Joint Working Group of Standard Setters, 1999). The JWG's most robust argument is that fair values provide value relevant information, which means that market returns are explained by earnings. On the other hand, defenders

Corresponding Author: Panayotis Manganaris, Department of Economics, Aristotle University of Thessaloniki,

Division of Business Administration, 54124 Thessaloniki, Greece

Tel: $+302310412321 /+306948758585$ 
of the conservatism principle express their disbelief in the virtues of fair valuation. According to this point of view, the fundamental structure of financial reporting does not allow for a unique application of fair valuation. Furthermore, the subjectivity and the difficulty of estimating fair values create even more problems towards full fair valuation (Chalmers and Godfrey, 2000).

The International Accounting Standards Board (IASB) decided that there would be a compromise between the two rival perceptions. Hence, when IAS 32 (presentation and disclosure of financial instruments) and IAS 39 (recognition and measurement of financial instruments) were issued, fair value was present, but on equal terms with historical cost valuation. As it turned out thought, the application of a mixed accounting treatment did not spawn the desirable results (Hellman, 2008).

In order to delineate an actual picture of the IFRS impact on the financial sector, this study examines the degree of conservatism and the value relevance in the selected countries during the last decade (1999-2009) both before and after the IFRS application (year 2005). Research for the first sub-period (1999-2004) has already provided important findings (Grambovas et al., 2006; Hung and Subramanyam, 2007; Kousenidis et al., 2009). However, evidence on the post-IFRS period is scarce.

This study expands previous research and deals with financial companies listed in the stock exchanges of four European countries: the UK, Germany, France and Greece. The selection of these countries is not random. Many surveys in the European accounting setting make discrimination between common-law and code-law countries. The UK belongs to the first group, while the other three countries belong-in broad terms-to the second group. Indeed, studies usually classify France and Germany in the same category of stakeholder-oriented regimes (Bushman and Piotroski, 2006; Gassen et al., 2006; Giner and Rees, 2001). Nevertheless, other studies stress the fact that there are essential differences between them. La Porta et al. (1998) segregate the French family of countries (more extreme differences from common-law tradition) from the German one (more efficient enforcement). According to them, France exhibits more profound differences from common-law countries than Germany does. The borderline between the two countries is also reinforced by Ball et al. (2000) who report that German accounting is presumably more conservative than the rest of the code-law countries. Lastly, although Greece's legal and judicial system bears remarkable similarities to the French model, the inclusion of Greece in the investigated sample stems from other institutional differences, especially in terms of public enforcement, risk of expropriation and ownership concentration (Bushman and Piotroski, 2006).

Our main effort focuses on (1) whether conditional conservatism exists in the European financial sector, (2) whether the level of conservatism changes after the mandatory application of IFRS and (3) whether a relationship between conservatism and value relevance exists and how is it affected by the IFRS enforcement. The results of the Basu model extend previous evidence on the European stock market by revealing that conservatism exists in the financial sector throughout the pre-IFRS period. At a statistically significant level, code-law countries become less conservative after implementing the IFRS, while the UK financial reporting becomes even more conservative. No specific pattern appears among the investigated accounting regimes when splitting the samples into high and lowconservatism companies, suggesting that countryspecific features also apply. In all code-law countries the explanatory power of the Easton and Harris model is higher in the pre-IFRS than in the post-IFRS period; the opposite stands for the UK. Moreover, our findings suggest that investors' perception on value relevance-in terms of firms' conservatism-has shifted after the introduction of IFRS. More specifically, during the second sub-period, higher conservatism entails less value relevant earnings, whereas low-conservatism firms exhibit more value relevance in their earningscontrary to the findings of the first sub-period. This is the case for all the investigated countries apart from Germany, which exhibits a reverse pattern.

The study is organized in the following way: firstly we determine the background of the study by analysing extant literature. We move on to the hypotheses and provide the methodology background and then the sample data. We continue with the empirical results of the survey and lastly, conclude with certain limitations and implications for further research.

\section{Research background:}

Conservatism: Over the last years, accounting conservatism has received a great deal of attention from empirical researchers. Much of this activity in the field has stemmed from Basu's (1997) asymmetric timeliness of earnings model.

According to Basu (1997), conservatism is interpreted as "capturing accountants' tendency to require a higher degree of verification for recognizing good news than bad news in financial statements". More timely recognition of 'bad news' in relation to 'good news' is a sign of conservatism and the 
corresponding model is based on this principle. Extant literature provides abundant terminology for this type of conservatism: income statement conservatism (Ball et al., 2000; Basu, 1997), export conservatism, news dependent conservatism (Chandra et al., 2004) (The other type of conservatism is unconditional conservatism (or balance-sheet or ex-ante or newsindependent conservatism) which escapes the focus of our study). For the purposes of this study, the term 'conditional conservatism' will be used (Ball and Shivakumar, 2005; Beaver and Ryan, 2005).

So far, literature has provided fruitful findings on conditional conservatism (Ball et al., 2000; Giner and Rees, 2001; Pope and Walker, 1999). Pope and Walker (1999) using ratios of bad-to-good-news as the parameters of their regression model find that conservatism exists in both the US and the UK accounting system. Moreover, when they use earnings after extraordinary items, the results on the degree of earnings conservatism between the two countries are similar. However, when using earnings before extraordinary items, the degree of earnings conservatism is higher in the US GAAP than in the UK GAAP. The greater level of earnings (conditional) conservatism in the US accounting setting is also consistent with Ball et al. (2000) who conducted a broader study among 7 countries with different institutional environments. They document that the degree of asymmetric timeliness varies substantially depending on the accounting framework and that conditional conservatism is higher in common-law countries than in code-law countries. However, they find that the UK accounting is marginally more conservative than accounting in code-law countries.

Two other studies attempt to examine whether Ball et al. (2000) results are valid in the European context. Giner and Rees (2001) confirm Ball et al. (2000) considering the existence of asymmetric timeliness in France, Germany and the UK, although they manifest that the differences across those three accounting regimes are not clear-cut despite their much different institutional and legal settings. A more recent study by García Lara and Mora (2004) reports the existence of earnings conservatism across eight European countries. However, they question Ball et al. (2000) results for the European territory and indicate that the higher degree of the asymmetric timeliness in the UK (common-law country) is statistically significant only when compared with Germany (code-law country), but not with the other investigated countries.

Empirical evidence exists also for the Greek context. Dimitropoulos and Asteriou (2008) provide evidence that conservatism exists in Greece and has increased between
1995 and 2004. Kousenidis et al. (2009) identify similar evidence for the period 1989-2003 and especially for the post-crisis (after 1999) period.

Value relevance: Value relevance of earnings is "the degree to which accounting earnings summarize information impounded in market prices" (Brown et al., 2006). Higher value relevance entails greater decision usefulness to investors (Barth et al., 1996).

Intuitively, one would expect data on current values to be value-relevant (Mozes, 2002). Indeed, according to Barlev and Haddad (2003), historical-cost based income statement does not reflect on the quality of earnings and is insufficient for investment decision making. On the other hand, value-relevance studiesmainly based on fair value disclosures-that focus on debt and equity securities for banks, thrifts, insurance companies and closed-end mutual funds (Ahmed and Takeda, 1995; Barth, 1994; Barth et al., 1996; Barth and Clinch, 1998; Beatty et al., 1996; Bernard et al., 1995; Petroni and Wahlen, 1995) provide rather substantial evidence that financial instruments' fair values are relevant to investors and reliable 'enough' to be reflected in share prices. Barth et al., (1996) find also that investors perceive the estimates of the fair value of bank loans more relevant than historical cost amounts, while Venkatachalam (1996) shows that investors perceive estimates of the fair value of derivatives to reflect more accurately than the notional amount of the derivatives, the underlying economic value.

However, before any fair-value regulations took place, Beaver et al. (1982) find that current cost data do not help explain cross-sectional differences in security prices, while Bernard and Ruland (1987) find that current cost data help explain time-series differences in security prices for only a small subset of firms. In addition, although Barth (1994) finds that fair value estimates of investment securities appear reliable and relevant to investors in valuing bank equity, she also recognizes that fair value securities gains and losses do not. Even Gebhardt et al. (2004) who find strong evidence in favour of fair value accounting within the German banking sector, admit that there are additional problems to overcome when extending fair value measurements to more classes of financial assets and liabilities (e.g., fair value measurement problems).

An interesting insight is given by a recent study in Greece (Iatridis and Rouvolis, 2010) which reports that IFRS adoption enhances value relevance of financial reporting. In the same country, Vazakidis and Athianos (2010) prove that the switch form Greek to international standards has affected the valuation of companies. In an international context, Francis and Shipper (1999) record 
a decreasing trend in the value relevance of earnings until 1994 (pre-IFRS period). The examination of whether the value relevance of earnings has changed after the IFRS adoption in Europe is a primary purpose of this study.

Conservatism and value relevance: Although the preceding analysis documents the popularity of both conditional conservatism and the value relevance of accounting information in recent research, there are not many studies directly involving both, especially in the European territory. So far, studies from the US have documented mixed results. Givoly and Hayn (2000) find that the level of earnings conservatism has increased from 1956-1998 and especially during the second half of the time period under investigation. Moreover, Lev and Zarowin (1999) have recorded a decrease in the value relevance of reported income over the same period (1977-1996), indicating that more conservatism is linked with less value relevance. On the other hand, more recent studies point to the opposite direction (Balachandran and Mohanram, 2006; Brown et al., 2006). Balachandran and Mohanram (2006) provide empirical evidence that both conditional and unconditional conservatism in the US are not associated with lowered value relevance. Brown et al. (2006) conduct an international study among 20 countries with various institutional settings and find that in countries with higher accrual intensity, conservatism is associated with a higher level of value-relevance.

Hellman (2008) investigates how the conservatism principle is applied in Europe under IFRS and reaches the conclusion that the mixing of consistent and temporary conservatism practices can reduce the value relevance of earnings information. Another study by Hung and Subramanyam (2007) in Germany is also sceptical about the usefulness of IFRS and suggests that that their adoption does not increase significantly either the timeliness of reported income or the value relevance of book value and net income.

Lastly, in Greece Kousenidis et al. (2009) observe a non linear relationship between conservatism and value relevance in a way that very high or very low conservatism is connected to lower levels of value relevance than medium conservatism does.

Common-law Vs. Code-law systems: Studies so far report a robust distinction between two accounting regimes within Europe: common-law-based or 'AngloSaxon' countries, where taxes are low, accounting practices are shareholder-oriented and the presence of corporate governance is profound (Pope and Walker,
1999) and code-law-based or 'continental' countries, where the prevalence of historical cost results in a taxdriven, law-based and stakeholder-oriented system that focuses on the determination of the distributable income by preventing firms from reporting unrealized revenues in their income (García Lara and Mora, 2004; Giner and Rees, 2001). Moreover, financial reporting standards are enforced in common-law countries in a more rigorous manner (Armstrong et al., 2010). Studies reveal that countries of the first group apply accounting methods that create more conditional conservatism in relation to countries of the second group. The UK is an illustrative example of the first group, whereas countries like France and Germany acquire accounting systems which belong to the category of countries that are affected by code law.

Differences between these systems emerge from deep-rooted factors, such as the legal system, which can affect both the conservatism level and the value relevance of accounting. A study by Bushman and Piotroski (2006, p.108) argues that "firms in countries with strong investor protections and high quality judicial systems reflect bad news in reported earnings numbers in a more timely fashion". Numerous other studies on conservatism provide evidence that its level can be linked to country-specific factors like contracting, litigation, taxation and regulation (Ball et al., 2000; Basu, 1997; García Lara and Mora, 2004; Holthausen and Watts, 2001; Raonic et al., 2004), as well as firm-specific attributes (Grambovas et al., 2006).

Other studies analyse the impact of each institutional setting on the relevance of accounting measures. For instance, Ali and Hwang (2000) find that countries where the accounting system follows the 'continental model' (i.e., code-law) exhibit lower value relevance of financial reports contrary to those countries which apply the 'British-American model' (i.e., common law). Moreover, shareholder protection-a feature evident in common-law regimes-appears to have a positive association with the value relevance of earnings (Hung, 2001).

Hung and Subramanyam (2007) provide some evidence on the impact of IFRS in German financial reporting; IFRS appear to provoke more conditional conservatism and more value relevance, but these results are not statistically significant. Of course, Germany has rigorous law enforcement and thus these results might not hold for other code-law countries like France and Greece.

\section{METERIALS AND METHODS}

This study makes an attempt to investigate the existence of conservatism and its effects on value 
relevance in the European financial sector. To do that, we firstly use the Basu (1997) model which measures conservatism as follows:

$$
\begin{aligned}
\mathrm{EPS}_{\mathrm{i}, \mathrm{t}} / \mathrm{P}_{\mathrm{i}, \mathrm{t}-1}=\beta_{0}+\beta_{1} \mathrm{DT}_{\mathrm{i}} \\
+\beta_{2} \operatorname{Ret}_{\mathrm{i}, \mathrm{t}}+\beta_{3} \operatorname{RetDT}_{\mathrm{i}, \mathrm{t}}+\varepsilon_{\mathrm{i}, \mathrm{t}}
\end{aligned}
$$

Where:

$\mathrm{EPS}_{\mathrm{i}, \mathrm{t}}=$ The earnings per share of firm $\mathrm{i}$ at year $\mathrm{t}$

$\mathrm{DT}_{\mathrm{i}, \mathrm{t}}=\mathrm{A}$ dummy variable that takes the value of 1 if returns of firm $i$ at year $t$ are negative and 0 otherwise

$\operatorname{Ret}_{\mathrm{i}, \mathrm{t}} \quad=$ The annual logarithmic difference of stock prices of firm $i$ at the end of year $t$

$\operatorname{RetDT}_{\mathrm{i}, \mathrm{t}}=$ The annual logarithmic difference of stock prices of firm $i$ at the end of year $t$ multiplied by the respective DT dummy

The asymmetry in the speed of recognition of bad news versus good news in earnings supports the description of conservatism according to Basu who claims that negative returns are recognized faster in earnings than the positive ones. Thus, the higher the value of the slope coefficient $\beta_{3}$, the greater the level of conservatism is.

Also, according to Raonic et al. (2004), $\beta_{0}$ is expected to have a negative sign whenever conservatism affects earnings, otherwise the sign will be positive. The same authors argue that when $\beta_{1}<0$, "deferred income recognition is scaled down" (Raonic et al., 2004).

After identifying the presence of conservatism in the financial sector as a whole, we proceed by dividing the sample into two portfolios, according to their level of conservatism and apply the Basu model in a similar way. The classification of the portfolios could have been made according to Balachandran and Mohanram (2006) and Kousenidis et al., (2009) by taking the lower and higher $30 \%$ for the two extreme portfolios and the remaining $40 \%$ for the medium-conservatism portfolio. We instead choose to split the sample into two portfolios $(50 \%$ for the low-conservatism portfolio denoted as $\mathrm{P} 1$ and $50 \%$ for the high-conservatism portfolio denoted as P2). The reasoning of this choice is based on the relatively small sample of firms, particularly in the case of Greece.

The model is applied on the total sample and each of the distinctive subsamples (Portfolios 1 and 2) in the following periods: (a) 1999-2008, (b) 1999-2004 and (c) 2005-2008 and the examination of significance at the 10, 5 and $1 \%$ level of the t-statistic of each coefficient is made by the asymptotic normal distribution. By comparing the significant coefficients among the above periods, we can induce whether the changes that have been caused by the implementation of IFRS have influenced the level of conservatism in the European financial firms.

The detection of the level of conservatism is followed by an attempt to measure the effects of conservatism on the value relevance of accounting information in the financial sector and the distinctive portfolios with the use of the Easton and Harris (1991) model:

$$
\operatorname{Ret}_{\mathrm{i}, \mathrm{t}}=\alpha_{0}+\alpha_{1} \frac{\mathrm{EPS}_{\mathrm{i}, \mathrm{t}}}{\mathrm{P}_{\mathrm{i}, \mathrm{t}-1}}+\alpha_{2} \frac{\Delta \mathrm{EPS}_{\mathrm{i}, \mathrm{t}}}{\mathrm{P}_{\mathrm{i}, \mathrm{t}-1}}+\varepsilon_{\mathrm{i}, \mathrm{t}}
$$

Where:

Ret $_{i, t}=$ The annual logarithm of stock returns of firm $\mathrm{i}$ at year $\mathrm{t}$

$\mathrm{P}_{\mathrm{i} . t,} \quad=$ The share price of firm $\mathrm{i}$ at year $\mathrm{t}$

$\mathrm{EPS}_{\mathrm{i}, \mathrm{t}}=$ The earnings per share of firm $\mathrm{i}$ at year $\mathrm{t}$

$\Delta \mathrm{EPS}_{\mathrm{it}}=$ The difference of earnings per share of firm $\mathrm{i}$ between two points in time

This model suggests that both the current earnings level and the earnings changes level have explanatory power on returns. Thus, the value relevance of earnings is measured by the t-statistics of the slope coefficients of the earnings and change in earnings variables, as well as the adjusted $\mathrm{R}^{2}$ (Francis and Scipper, 1999). According to Feltham and Ohlson, (1995), $\alpha_{2}$ depicts the influence of the stock price changes on the returns, while $\alpha_{1}$ weights the influence of the book values on the returns.

Fixed/Random cross-section effects have been taken into consideration to control for issues of heterogeneity. The Hausman (1978) test has been used in this case. In most cases the effects were random and whenever fixed effects were present, the appropriate notation has been made in the tables.

Based on the previous analysis, the research hypotheses are the following:

$\mathrm{H}_{1}=$ Conservatism is absent from the data

$\mathrm{H}_{2}=$ Conservatism is lower for the post-IFRS period than for the pre-IFRS period

$\mathrm{H}_{3}=$ Conservatism is lower in code-law countries than in common-law countries after the IFRS application.

$\mathrm{H}_{4}=$ Value relevance of earnings is higher in commonlaw countries than in code-law countries

$\mathrm{H}_{5}=$ Value relevance of earnings is higher when conservatism is present

Data selection: Authors studying conservatism and value relevance usually exclude non-financial 
companies from their statistical sample. Instead of following the usual path, we decided to include in our sample only the financial sector. Raonic et al. (2004) also include financial firms in their sample, but only as part of a broader dataset. Additionally, financial sector is the one that has been influenced the most from the application of IAS 32 and 39 and IFRS 7 (banking sector) as well as IFRS 4 (insurance companies). Therefore, comparing financial firms for two separate time periods (before and after IFRS application) can produce useful evidence about the impact of these standards.

The available data sample was retrieved from electronic financial statements. The data employed in the empirical analysis are annual figures from 321 public firms that operate in the financial sector of four European countries: the UK (127), Germany (95), France (76) and Greece (23). By the term 'financial sector' we refer to all companies whose primary business activity belongs to the banking, insurance, real estate, investment or financial services sector. Sixteen firms were deleted from the initial sample either due to fact that they presented limited observations or because they became inactive throughout this period. In order to improve the robustness of the Basu model, we excluded companies that did not provide full data for at least 7 years. Also, each sample company should have observations for at least 3 years in the pre-IFRS period and 3 years in the post-IFRS period. The upper and lower $1 \%$ of earnings or stock price returns in each country sub-sample was also banned from the final sample in order to reduce the effect $\mathrm{s}$ of outliers on the regression results. The final sample came out with 305 firms and 2565 firm year observations.

The selected time period spans between 1999 (the year after the Russian stock market crisis) and 2008 (the year of the global financial crisis). Crises usually reinforce conservatism and this is being investigated in the first half of the investigated decade. But, the most important criterion for selecting this decade is that it can be equally split in two sub-periods (before and after IFRS application), i.e., 1999-2004 and 2005-2009. Previous studies have examined conservatism in a similar context, but not for this time horizon. Although, the incorporation of more years-especially in the postIFRS period-would be useful, the inclusion of the 19992009 decade is still sufficient.

\section{RESULTS}

Table 1 (Panel A) presents the results that were derived from the Basu model for each of the four countries. The first row of each country refers to the whole period under examination, while the other two rows refer to each one of the two sub-periods. Results for the $\beta_{3}$ coefficient are positive and statistically significant for all countries during the decade-apart from Greece where the positive $\beta_{3}$ is not statistically significant. The UK exhibits higher levels of conservatism in relation to the code-law countries. We can, therefore, imply that conservatism exists in the European context throughout the whole decade and $\mathrm{H}_{1}$ can be rejected.

Splitting the country samples into two sub-periods reveals more specific insights. In particular, in Germany the $\beta_{3}$ coefficient appears to be positive and statistically significant in both sub-periods following a downward trend. This trend is also recorded for France; in fact, the $\beta_{3}$ slope in the post-IFRS period becomes negative for France $(p<0.05)$. These findings do not agree with the idea that the IFRS have imposed more conservative practices in accounting and thus we cannot reject our initial hypothesis $\left(\mathrm{H}_{2}\right)$ that the IFRS reduce conservatism-at least for the code-law countries. On the contrary, the UK has adopted even more conservative accounting practices after the IFRS adoption $(\mathrm{p}<0.01)$. We can therefore imply that code-law financial firms became less conservative since the introduction of the IFRS, while the opposite is true for the common-law firms, thus $\mathrm{H}_{3}$ cannot be rejected. The case of Greece though is different: conservatism appears in the preIFRS period (which is consistent with extant literature), but the introduction of the IFRS has led to even more conservative financial reporting, although this country's results do not bear statistical significance.

The $\beta_{2}$ slope coefficient is positive and significant only in the case of France and only for the second subperiod. The fact that it is accompanied by a negative $\beta_{3}$ with statistical significance suggests that it was mainly the 'good news' rather than the 'bad news' that affected the earnings after the IFRS adoption; this implication partly explains the reduced level of conservatism for this specific period. No other country exhibits statistically significant $\beta_{2}$, which is in consistency with the existence of conservatism. The adjusted $\mathrm{R}^{2} \mathrm{~s}$ are relatively low, but satisfactory considering previous studies. All countries exhibit higher adjusted $\mathrm{R}^{2}$ in the pre-IFRS period, meaning that before the adoption of the IFRS, the Basu model could better explain the variability of the level of conservatism in the financial market.

A few more findings can be acquired by dividing the initial sample into separate portfolios of conservatism. Panel B of Table 1 quotes the results based on the two conservatism portfolios and the period segmentation for each one of them. France and UK exhibit the most statistically significant $\beta_{3}$ coefficients. Especially the low-conservatism portfolio $\left(\mathrm{P}_{1}\right)$ in these two countries is significant not only for the whole period $(\mathrm{p}<0.05)$, but for each sub-period as well 
$(p<0.01)$. The most remarkable finding is the different impact that the IFRS have on each country's conservatism. For instance, highly conservative German and French firms have lower (negative) levels of conservatism in the 2005-2008 period, in contrast to the corresponding portfolio of the UK where conservatism is slightly higher after the IFRS adoption. However, differences exist even among code-law countries: German low-conservatism firms $\left(\mathrm{P}_{1}\right)$ have adopted even more conservative accounting practices after 2005, contrary to France's $P_{1}$. Greece's portfolios, on the other hand, behave similarly to each other by having increased the degree of conservatism due to the new set of standards. In general, the implementation of the IFRS in Europe has provoked different shifts in each country's conditional conservatism, suggesting that apart from the institutional setting (either code or common law), there are also other country-specific factors affecting conservatism.

Table 2 (Panel A) depicts the Easton and Harris model and how it behaves depending on the conservatism level. Once again the quoted results are segmented according to the conservatism portfolio and the time period. The constant $\alpha_{0}$ refers to the secure returns, which are positive and statistically significant at a $p<0,01$ level for all countries except for Greece, but after the IFRS implementation all financial firms have recorded lower secure returns; nonetheless, the lack of statistical significance during the post-IFRS period hinders us from concluding that the IFRS have provoked diminished returns.

Table 1: Basu (1997) model results

\begin{tabular}{|c|c|c|c|c|c|c|}
\hline$\overline{\text { Panel A }}$ & Greece & $\beta_{0}$ & $\beta_{1}$ & $\beta_{2}$ & $\beta_{3}$ & $\mathrm{R}^{2}$ \\
\hline & 1999-2008 & $0.12 * *$ & -0.02 & -0.01 & 0.02 & 0.02 \\
\hline & Pre-IFRS & $0.05^{*}$ & -0.01 & 0.01 & 0.01 & 0.01 \\
\hline & Post-IFRS & $0.17 *$ & 0.14 & -0.01 & 0.16 & 0.01 \\
\hline & $\begin{array}{l}\text { France } \\
1999-2008\end{array}$ & & & & & \\
\hline & $\begin{array}{l}\text { 1999-2008 } \\
\text { Pre-IFRS }\end{array}$ & $\begin{array}{l}0.19 * * * \\
010 * * *\end{array}$ & $-0.18^{*}$ & 0.03 & $0.04 * * *$ & 0.03 \\
\hline & $\begin{array}{l}\text { Pre-IFRS } \\
\text { Post-IFRS }\end{array}$ & $\begin{array}{l}0.10^{* * *} \\
0.06\end{array}$ & $-0.05^{*}$ & -0.01 & 0.05 & 0.67 \\
\hline & $\begin{array}{l}\text { Post-IFRS } \\
\text { Germany }\end{array}$ & 0.06 & -0.13 & $0.18^{* * *}$ & $-0.09 * *$ & 0.09 \\
\hline & $1999-2008$ & 0.02 & $-0.19 * * *$ & -0.01 & $0.08 * * *$ & 0.05 \\
\hline & Pre-IFRS & 0.01 & $-0.14 * *$ & -0.02 & $0.13^{* * *}$ & 0.07 \\
\hline & Post-IFRS & 0.04 & $-0.25 * * *$ & 0.01 & $0.06^{* *}$ & 0.05 \\
\hline & $\begin{array}{l}\text { UK } \\
1999-2008\end{array}$ & 0.01 & & & & \\
\hline & $\begin{array}{l}199-2008 \\
\text { Pre-IFRS }\end{array}$ & $\begin{array}{l}0.01 \\
0.01\end{array}$ & $0.08^{* * *}$ & -0.01 & $0.37 * * *$ & 0.05 \\
\hline & Post-IFRS & 0.01 & $\begin{array}{l}-0.01 \\
0.12 * *\end{array}$ & $\begin{array}{r}-0.01 \\
0.01\end{array}$ & 0.01 & $\begin{array}{l}0.22 \\
0.05\end{array}$ \\
\hline \multirow{30}{*}{ Panel B } & Greece-P ${ }_{1}$ & & & & & \\
\hline & $1999-2008$ & $0.07 *$ & $-0.13 * *$ & -0.01 & 0.01 & 0.04 \\
\hline & Pre-IFRS & -0.01 & -0.06 & 0.02 & -0.04 & 0.01 \\
\hline & Post-IFRS & 0.12 & -0.11 & -0.01 & 0.17 & 0.26 \\
\hline & Greece-P ${ }_{2}$ & & & & & \\
\hline & $1999-2008$ & $0.20 *$ & -0.03 & -0.01 & 0.05 & 0.01 \\
\hline & Pre-IFRS & 0.16 & 0.07 & 0.01 & 0.04 & 0.02 \\
\hline & Post-IFRS & 0.27 & -0.19 & -0.03 & 0.08 & 0.01 \\
\hline & France- $P_{1}$ & & & & & \\
\hline & $1999-2008$ & -0.02 & $-0.37 * * *$ & -0.01 & $0.03 * *$ & 0.06 \\
\hline & Pre-IFRS & -0.04 & $-0.26 * *$ & -0.01 & $0.11^{*}$ & 0.05 \\
\hline & Post-IFRS & 0.01 & $-0.51 * * *$ & 0.01 & $0.02 *$ & 0.07 \\
\hline & France- $P_{2}$ & & & & & \\
\hline & $1999-2008$ & 0.33 & $0.17 *$ & $0.33^{* * *}$ & $0.02 * *$ & 0.22 \\
\hline & Pre-IFRS & 0.28 & 0.18 & -0.02 & 0.05 & 0.01 \\
\hline & Post-IFRS & $0.43^{*}$ & 0.19 & $0.35 * * *$ & -0.05 & 0.56 \\
\hline & 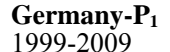 & -0.16 & -2.41 & 0.01 & 0.07 & 002 \\
\hline & Pre-IFRS & -1.07 & -2.23 & $\begin{array}{l}0.01 \\
1.08\end{array}$ & $\begin{array}{l}0.01 \\
-0.38\end{array}$ & 0.15 \\
\hline & post-IFRS & -1.62 & 1.21 & -0.03 & 0.09 & 0.01 \\
\hline & Germany-P $\mathbf{P}_{2}$ & $005 * * *$ & (20? & 0.01 & 012 & \\
\hline & Pre-IFRS & $0.05 * * *$ & -0.02 & -0.01 & 0.12 & 0.01 \\
\hline & Post-IFRS & $0.06 * * *$ & $\begin{array}{l}-0.01 \\
-0.04\end{array}$ & $\begin{array}{l}-0.01 \\
-0.01\end{array}$ & $\begin{array}{c}0.19^{*} \\
-0.05\end{array}$ & 0.02 \\
\hline & UK-P ${ }_{1}$ & 0.06 & -0.04 & -0.01 & -0.05 & 0.01 \\
\hline & $1999-2008$ & -0.01 & $-0.01 * *$ & -0.01 & $0.01 * *$ & 0.03 \\
\hline & Pre-IFRS & -0.01 & $-0.02 *$ & -0.01 & $0.01 *$ & 0.02 \\
\hline & Post-IFRS & 0.01 & -0.01 & -0.01 & $0.01 *$ & 0.02 \\
\hline & UK-P $\mathbf{P}_{2}$ & & & & & \\
\hline & $1999-2008$ & $0.01 * * *$ & 0.01 & $0.01 *$ & $0.02 * *$ & 0.81 \\
\hline & Pre-IFRS & 0.01 & -0.01 & $0.01 * * *$ & -0.01 & 0.07 \\
\hline & Post-IFRS & $0.01 * * *$ & -0.01 & 0.01 & 0.02 & 0.64 \\
\hline
\end{tabular}


Am. J. of Economics and Business Administration 3 (2): 259-269, 2011

Moreover, the adjusted $\mathrm{R}^{2}$ values appear higher in the prior-to-IFRS period than in the after-IFRS period for all code-law regions; the opposite is true for the UK financial firms, suggesting that in 'continental' countries the IFRS have decreased the value relevance of earnings. This is also verified by the change in earnings $\left(\alpha_{2}\right)$ which has significant explanatory power in all countries and for all time periods. The higher $\alpha_{2}$ value is recorded in the UK, not only for the entire period, but also for the 2005-2008 period. Earnings, as proxied by the $\alpha_{1}$ coefficient, also provide a certain level of informativeness in the model, but especially for Germany (entire period and pre-IFRS period, $\mathrm{p}<0.01$ ). To sum up, although the UK results demonstrate better goodness of fit (higher value relevance) through time, the Easton and Harris model also works well for the code-law financial sector, especially in the pre-IFRS period. Thus, $\mathrm{H}_{4}$ cannot be rejected.

Panel B of Table 2 allows us to clarify the relationship between conservatism and value relevance. The adjusted $\mathrm{R}^{2}$ values suggest that, excepting Germany, $\mathrm{P}_{2}$ (high-conservatism portfolio) outperforms $\mathrm{P}_{1}$ in all other countries and thus, $\mathrm{H}_{5}$ cannot be rejected. Furthermore, the $\alpha_{2}$ coefficient, which is statistically significant in most cases, provides similar implications and additional explanatory power to the model.

The $\alpha_{1}$ coefficient is particularly significant for the highly conservative UK firms and for both high and low-conservative German firms. All the above suggest that in Germany both earnings and book values are taken into consideration when making investment decisions, irrespective of the conservatism level of each financial company. In the UK this is true only when dealing with high-conservatism companies.

In terms of each separate sub-period, the main trend is the following: in the second period (2005-2008) firms with low conservatism exhibit higher value relevance, whereas firms with high conservatism are less value-relevant. Hence, more conservatism leads to less value relevance in the post-IFRS period and vice versa. Again, Germany is the exception to this pattern, showing reverse results.

Also, most of the $\alpha_{2}$ coefficients-and several $\alpha_{1}$ coefficients-add to the model's explanatory power for returns both before and after the IFRS implementation. For instance, when looking at high-conservatism UK financial firms or at high and low-conservatism German financial firms, both the earnings variable and the change in earnings variable are good estimates of that period's returns. The fact that this statistical significance is accompanied by a reasonably high adjusted $R^{2}$ adds robustness to the findings. On average, the results reveal mixed reactions after the adoption of the new set of standards depending on the accounting setting and the existing conservatism level.
Table 2: Easton and Harris (1991) model result

\begin{tabular}{|c|c|c|c|c|}
\hline Greece & $\alpha_{0}$ & $\alpha_{1}$ & $\alpha_{2}$ & $\mathrm{R}^{2}$ \\
\hline Panel A 1999-2008 & 0.12 & -0.38 & $3.61 * * *$ & 0.31 \\
\hline Pre-IFRS & 0.18 & $-2.84 *$ & $4.51 * * *$ & 0.30 \\
\hline Post-IFRS & 0.08 & $-0.25^{*}$ & $1.33 * * *$ & 0.16 \\
\hline \multicolumn{5}{|l|}{ France } \\
\hline $1999-2008$ & $0.09 * * *$ & $0.04 *$ & $0.01 * *$ & 0.02 \\
\hline Pre-IFRS & $0.16^{* * *}$ & 0.12 & $0.43 *$ & 0.01 \\
\hline Post-IFRS & -0.01 & 0.03 & $0.01 *$ & 0.00 \\
\hline \multicolumn{5}{|l|}{ Germany } \\
\hline $1999-2008$ & $0.07 * * *$ & $0.19 * * *$ & $0.19 * * *$ & 0.07 \\
\hline Pre-IFRS & 0.02 & $0.20 * * *$ & $0.16^{* * *}$ & 0.09 \\
\hline Post-IFRS & -0.01 & 0.03 & $0.01^{*}$ & 0.00 \\
\hline \multicolumn{5}{|l|}{ UK } \\
\hline $1999-2008$ & $0.08 * * *$ & 0.11 & $7.01 * * *$ & 0.02 \\
\hline Pre-IFRS & $0.16^{* * *}$ & -0.11 & $3.93^{*}$ & 0.00 \\
\hline Post-IFRS & -0.01 & 0.10 & $6.68 * * *$ & 0.05 \\
\hline \multicolumn{5}{|l|}{ Panel B Greece-P $\mathbf{1}_{\mathbf{1}}$} \\
\hline $1999-2008$ & 0.06 & 1.18 & -0.05 & 0.00 \\
\hline Pre-IFRS & 0.14 & 0.71 & -0.02 & 0.00 \\
\hline Post-IFRS & -0.06 & $1.11 * *$ & -0.04 & 0.39 \\
\hline \multicolumn{5}{|l|}{ Greece-P ${ }_{2}$} \\
\hline $1999-2008$ & 0.12 & -0.27 & $2.74 * * *$ & 0.71 \\
\hline Pre-IFRS & $0.43 *$ & $-2.34 * *$ & $3.04 * * *$ & 0.86 \\
\hline Post-IFRS & 0.07 & -0.02 & $0.40 * *$ & 0.13 \\
\hline \multicolumn{5}{|l|}{ France- $P_{1}$} \\
\hline 1999-2008 & $0.09 * * *$ & 0.01 & $0.40 * *$ & 0.00 \\
\hline Pre-IFRS & $0.16^{* * *}$ & $-0.06 *$ & 0.19 & 0.04 \\
\hline post-IFRS & 0.02 & 0.01 & $0.49 * *$ & 0.05 \\
\hline \multicolumn{5}{|l|}{ France- $\mathbf{P}_{2}$} \\
\hline 1999-2008 & $0.10^{* *}$ & 0.04 & $0.01 *$ & 0.02 \\
\hline Pre-IFRS & $0.27 * * *$ & $-0.21 *$ & $0.76^{* *} *$ & 0.04 \\
\hline Post-IFRS & -0.01 & -0.01 & 0.01 & 0.03 \\
\hline \multicolumn{5}{|l|}{ Germany-P $\mathbf{P}_{1}$} \\
\hline $1999-2008$ & $0.08 *$ & $0.20 * * *$ & $0.18 * * *$ & 0.10 \\
\hline Pre-IFRS & 0.01 & $0.19 * * *$ & $0.16^{* * *}$ & 0.13 \\
\hline Post-IFRS & $0.17 *$ & $0.18 *$ & $0.44 *$ & 0.08 \\
\hline \multicolumn{5}{|c|}{ Germany-P $\mathbf{P}_{2}$} \\
\hline $1999-2008$ & $0.13 * * *$ & $-1.33 * * *$ & $0.88 * * *$ & 0.03 \\
\hline Pre-IFRS & 0.04 & 0.03 & $0.52 *$ & 0.01 \\
\hline Post-IFRS & $0.33 * * *$ & $-3.91 * * *$ & $1.90 * * *$ & 0.04 \\
\hline \multicolumn{5}{|l|}{ UK-P $P_{1}$} \\
\hline $1999-2008$ & $0.08 *$ & 0.60 & $5.07 * *$ & 0.02 \\
\hline Pre-IFRS & $0.20 * *$ & 1.41 & 0.24 & 0.00 \\
\hline Post-IFRS & -0.04 & -0.97 & $5.44 * * *$ & 0.08 \\
\hline \multicolumn{5}{|l|}{ UK-P $\mathbf{P}_{2}$} \\
\hline $1999-2008$ & 0.02 & $2.74 * * *$ & $-2.76^{* *}$ & 0.03 \\
\hline Pre-IFRS & 0.06 & $2.42 * *$ & $4.09 * * *$ & 0.11 \\
\hline Post-IFRS & $-0.16^{* * *}$ & $3.83 * * *$ & $-3.97 * * *$ & 0.00 \\
\hline
\end{tabular}

\section{DISCUSSION}

This study examines the levels of conservatism and value relevance existent in the financial sectors of three code law European countries (Germany, France and Greece) and one common law European country (UK). Studies usually focus (a) on developed markets and (b) on the non-financial sector. Moving against this research regularity, the focus of this study is on financial firms. Alongside, a primary objective of this study is to test whether the results found in France and Germany are consistent with smaller code-law markets as well, such as Greece. 
We firstly attempt to measure whether conservatism exists during the last decade (1999-2008) and whether its level has changed over this period. According to the IASB, conservatism is an undesirable feature in financial reporting, therefore we expect less conservatism in the post-IFRS period. We provide evidence that conservatism exists and we verify extant literature, for instance Grambovas et al. (2006), who find that the EU-when taken as a whole-has become more conservative after 1989 . We also find that the UK exhibits the highest level of conservatism when examining the entire time period. Additionally, splitting the country samples into two sub-periods reveals that code-law firms become less conservative since the introduction of the IFRS, while the opposite is true for the common-law companies. We agree with Dimitropoulos and Asteriou (2008) that the Basu model does not work effectively in the Greek capital market.

Each sample is also divided into separate portfolios of conservatism (high and low). Statistically significant results show that France's low-conservatism portfolio becomes less conservative in the post-IFRS period, while the $U K P_{1}$ firms retain the same levels of conservatism. At the same time, highly conservative German and French firms have lower (negative) levels of conservatism in the post-IFRS period, in contrast to the corresponding portfolio of the UK where conservatism is slightly higher after the IFRS adoption. The small changes in conservatism on the two UK portfolios are in consistency with Ali and Hwang (2000), who point out that common-law financial reporting appears resemblances with IFRS. Additionally, apart from the similarities there are also differences among 'continental' countries, implying (a) that the IFRS had a different impact on each country's conditional conservatism and (b) that apart from the institutional setting (either code or common law), there are also other country-specific factors affecting conservatism.

Furthermore, this study investigates the impact of conservatism on the value relevance of earnings taking each country's sample as a whole, but also by splitting the sample according to (a) the level of the firms' conservatism and (b) the period before and after the IFRS adoption. In the post-IFRS period 'continental' countries have decreased value relevance of earnings; on the contrary, the UK demonstrates better goodness of fit (higher value relevance) through time. Overall, the Easton and Harris model works well, especially in the pre-IFRS period. Also, in the post-IFRS period more conservatism leads to less value relevance and vice versa; this is the case with all countries apart from Germany, which exhibits reverse findings.

Evidence documents that despite grouping Greece, Germany and France together as code-law countries, each one of them exhibits different trends in both the conservatism level and the value relevance of earnings. This is consistent with Ball et al. (2000) who observe that differences in earnings conservatism can be partly attributed to different country-specific behavioural patterns that affect differently the accounting system, but that are not reflected in a set of standards (i.e., IFRS). Moreover, our findings verify García Lara and Mora (2004) who argue that "the differences in earnings conservatism across countries will continue to hold even after implementing a common set of standards as long as the differences in institutional factors remain".

A main feature of this study is the comparison of two periods - before and after the IFRS introduction, which allows readers to assess the impact of the new set of standards on Europe. Another contribution of this study is that it provides evidence that conservatism exists-mainly during the pre-IFRS period-in the financial sector. It also covers a gap on the conservatism literature, which has mainly dealt with the non-financial sector.

\section{CONCLUSION}

For the purpose of our analysis, we intentionally selected one illustrative common-law country and three code-law countries, although Germany is not unanimously considered as a code-law country. Moreover, France and Greece, although both strictly code-law countries, were selected due to their fundamental differences (the latter is a smaller and lessdeveloped country). Thus, the four-country sample provides different insights for every one of them and the institutional setting they represent, as discussed above.

Our research possesses features that distinguish it from other studies in the field. For instance, when most of the conservatism and value-relevance studies prefer using non-financial firms as samples, our research focuses on the European financial sector. Alongside, this research takes a 10-year period not only as a whole, but also cut in the middle in order to gauge the IFRS effect. We also split each country's sample in half according to the level of conservatism in order to associate conservatism with value relevance.

To the best of our knowledge, this is the first approach to the assessment of conservatism and value relevance in the European financial sector. A certain limitation that should be taken into consideration when interpreting these results is the relatively narrow period of time. Of course, panel data statistics can reach safe results even with a limited time span. Nonetheless, the 
incorporation of more years (preferably in the postIFRS period) or the comparison between the financial and non-financial firms could enhance the usefulness of the findings. Also, the existence of potential bias in the estimated coefficients due to the possibility of presence of cross-sectional correlation in the error terms of the regressions can harm the interpretation of empirical results. Next studies on this field should take into consideration this parameter. Lastly, the fact that we included the whole financial sector in the analysis might have induced certain inconsistency in the results. Further research should isolate the banking sector or any other sector from the rest of the financial firms, due to certain particularities that necessitate separate investigation.

\section{REFERENCES}

Ahmed, A.S. and C. Takeda, 1995. Stock market valuation of gains and losses on commercial banks' investment securities an empirical analysis. J. Accoun. Econ., 20: 207-225.

Ali, A. and L. Hwang, 2000. Country-specific factors related to financial reporting and the value relevance of accounting data. J. Accoun. Res., 38: $1-21$.

Armstrong, C., M. Barth, A. Jagolinzer and E. Riedl, 2010. Market reaction to the adoption of IFRS in Europe. Accoun. Rev., 85: 31-61.

Balachandran, S.V. and P.S. Mohanram, 2006. Conservatism and the value relevance of accounting information. Unpublished working paper, Columbia University. http://papers.ssrn.com/sol3/papers.cfm?abstract_id $=1670508$

Ball, R. and L. Shivakumar, 2005. Earnings quality in UK private firms: comparative loss recognition timeliness. J. Accoun. Econ., 39: 83-128.

Ball, R., S.P. Kothari and A. Robin, 2000. The effect of international institutional factors on properties of accounting earnings. J. Accoun. Econ., 29: 1-51.

Barlev, B. and J.R. Haddad, 2003. Fair value accounting and the management of the Firm. Critical Perspectives Accoun., 14: 383-415. DOI: 10.1016/S1045-2354(02)00139-9

Barth, M.E. and G. Clinch, 1998. Revalued financial, tangible, and intangible assets: Associations with share prices and non-market-based value estimates. J. Accoun. Res., 36: 199-233.

Barth, M.E., 1994. Fair value accounting: Evidence from investment securities and the market valuation of banks. Accoun. Rev., 69: 1-25.

Barth, M.E., W.H. Beaver and W.R. Landsman, 1996. Value-relevance of banks' fair value disclosures under SFAS No. 107. Accoun. Rev., 71: 513-537.
Basu, S., 1997. The conservatism principle and the asymmetric timeliness of earnings. J. Accoun. Econ., 24: 3-37. DOI: 10.1016/S01654101(97)00014-1

Beatty, A., S. Chamberlain and J. Magliolo, 1996. An empirical analysis of the economic implications of fair value accounting for investment securities. J. Accoun. Econ., 22: 43-77.

Beaver, W.H. and S.G. Ryan, 2005. Conditional and unconditional conservatism: Concepts and modeling. Rev. Accoun. Stud., 10: 269-309. DOI: 10.1007/s11142-005-1532-6

Beaver, W.H., P.A. Griffin and W.R. Landsman, 1982. The incremental information content of replacement cost earnings. J. Accoun. Econ., 4: 15-39.

Bernard, V.L. and R.G. Ruland, 1987. The incremental information content of historical cost and current cost income numbers: Time-series analyses for 1962-1980. Accoun. Rev., 62: 707-722.

Bernard, V.L., R.C. Merton and K.G. Palepu, 1995. Mark-to-market accounting for banks and thrifts: Lessons from the Danish experience. J. Accoun. Res., 33: 1-32.

Brown, W.J., H. He and K. Teitel, 2006. Conditional conservatism and the value relevance of accounting earnings: An international study. Eur. Accoun. Rev., $\quad$ 15: 605-626. DOI: 10.1080/09638180601102198

Bushman, R.M. and J.D. Piotroski, 2006. Financial reporting incentives for conservative accounting: The influence of legal and political institutions. J. Accoun. Econ., 42: 107-148.

Chalmers, K. and J.M. Godfrey, 2004. Reputation costs: The impetus for voluntary derivative financial instrument reporting. Accoun. Organ. Soc., 29: $95-125$. DOI: 10.1016/S03613682(02)00034-X

Chandra, U., C. Wasley and G. Waymire, 2004. Income conservatism in the U.S. technology sector: Unpublished working paper, University of Rochester.

http://papers.ssrn.com/sol3/papers.cfm?abstract_id $=485064$

Dimitropoulos, P. and D. Asteriou, 2008. Timeliness, conservatism and financial transparent firms under the Greek accounting setting. Rev. Accoun. Finance, 7: 252-269.

Easton, P.D. and T.S. Harris, 1991. Earnings as an explanatory variable for returns. J. Accoun. Res., 29: 19-36.

Feltham, G. and J. Ohlson, 1995. Valuation and clean surplus accounting for operating and financial activities. Contemporary Accoun. Res., 11: 689-731. DOI: 10.1111/j.1911-3846.1995.tb00462.x 
Francis, J. and K. Schipper, 1999. Have financial statements lost their relevance? J. Accoun. Res., 37: 319-352.

García Lara, J.M. and A. Mora, 2004. Balance sheet versus earnings conservatism in Europe. Eur. Accoun. Rev., 13: 261-292.

Gassen, J., R.U. Fulbier and T. Sellhorn, 2006. International differences in conditional conservatism-The role of unconditional conservatism and income smoothing. Eur. Accoun. Rev., 15: 527-564. DOI: 10.1080/09638180601102107

Gebhardt, G., R. Reichardt and C. Wittenbrink, 2004. Accounting for financial instruments in the banking industry: Conclusions from a simulation model. Eur. Accoun. Rev., 13: 341-371.

Giner, B. and W.P. Rees, 2001. On the asymmetric recognition of good and bad news in France, Germany and the United Kingdom. J. Bus. Finance Accoun., 28: 1285-1331.

Givoly, D. and C. Hayn, 2000. The changing timeseries properties of earnings, cash flows and accruals: Has financial reporting become more conservative? J. Accoun Econ., 29: 287-320.

Grambovas, C.A., B. Giner and D. Christodoulou, 2006. Earnings conservatism: panel data evidence from the European Union and the United States. Abacus, 42: 354-378.

Hausman, J.A., 1978. Specification tests in econometrics. Econometrica, 46: 1251-1271. http://ideas.repec.org/a/ecm/emetrp/v46y1978i6p1 251-71.html

Hellman, N., 2008. Accounting conservatism under IFRS. Accoun. Europe, 5: 71-100. DOI: 10.1080/17449480802510492

Holthausen, R.W. and R.L. Watts, 2001. The relevance of the value-relevance literature for financial accounting standard setting. J. Accoun. Econ., 31: 3-75.

Hung, M. and K.R. Subramanyam, 2007. Financial statement effects of adopting international accounting standards: The case of Germany. Rev. Accoun. Studies, 12: 623-657. DOI: 10.1007/s11142-007-9049-9
Hung, M., 2001. Accounting standards and value relevance of financial statements: An international analysis. J. Accoun. Econ., 30: 401-420.

Iatridis, G. and S. Rouvolis, 2010. The post-adoption effects of the implementation of international financial reporting standards in Greece. J. Int. Accoun. Auditing Taxation, 19: 55-65. DOI: 10.1016/j.intaccaudtax.2009.12.004

Joint Working Group of Standard Setters, 1999. Financial Instruments and Similar Items-Draft Standard and Basis for Conclusions (London). http://www.iasplus.com/resource/fijwg-1.pdf

Kousenidis, D.V., A.C. Ladas and C.I. Negakis, 2009. Value relevance of conservative and nonconservative accounting information. Int. J. Accoun., 44: 219-238. DOI: 10.1016/j.intacc.2009.06.006

La Porta, R., F. Lopez-de-Silanes, A. Shleifer and R.W. Vishny, 1998. Law and Finance. J. Political Economy, 106: 1113-1155.

Lev, B. and P. Zarowin, 1999. The boundaries of financial reporting and how to extend them. J. Accoun. Res., 37: 353-385.

Mozes, H.A., 2002. The value relevance of financial institutions' fair value disclosures: A study in the difficulty of linking unrealized gains and losses to equity values. Abacus, 38: 1-15.

Petroni, K.R. and J.M. Wahlen, 1995. Fair values of equity and debt securities and share prices of property-liability insurers. J. Risk Insurance, 62: 719-737.

Pope, P.F. and M. Walker, 1999. International differences in the timeliness, conservatism, and classification of earnings. Studies on Credible Financial Reporting. J. Accoun. Res., 37: 53-87.

Raonic, I., S. McLeay and I. Asimakopoulos, 2004. The timeliness of income recognition by European companies: An analysis of institutional and market complexity. J. Bus. Finance Accoun., 31: 115-148.

Vazakidis, A. and S. Athianos, 2010. Measuring investors' reaction to the adoption of international financial reporting standards in greece, using a market-based model. Am. J. Econ. Bus. Admin., 2: 103-112. DOI: 10.3844/ajebasp.2010.103.112

Venkatachalam, M., 1996. Value-relevance of banks' derivatives disclosures. J. Accoun. Econ., 22: 327-355. 